\title{
Mineralogy and diagenetic impacts on chemical composition of Paleozoic mudrocks, southwestern Sinai, Egypt
}

\author{
S. D. Abayazeed ${ }^{1 *}$ (D, A. M. Ibrahim², Abdalla Soliman Alshami and D. A. Saadawy ${ }^{2}$
}

\begin{abstract}
Background: The present study deals with mineralogy, diagenesis, and their impact on chemical composition for early Paleozoic, Cambro-Ordovician, (Adediya and Abu Hamata formations) and late Paleozoic, early Carboniferous, (El Hashash and Magharet El Maiah) mudrocks at the southwestern Sinai area. Mineralogical study reveals the presence of kaolinite and illite clay minerals.

Conclusions: The detection of kaolinite and illite clay minerals favors that the environment of formation was alkaline, and the origin of the clay minerals present is chlorite more probably than illite origin where illite can be derived from the weathering of chlorite.

Diagenetic study reveals that kaolinite can be neo-formed, transformed at high rainfall and a temperate climate which can transform muscovite and biotite into kaolinite together with some illite. Chemical composition study, abundance, behavior, and distribution of major and trace components reveals that the studied mudrocks seem to be formed under reducing alkaline environment.
\end{abstract}

Keywords: Paleozoic mudrocks, Southwestern Sinai, Mineralogy, Paleoenvironment, Diagenesis, Kaolinite, Illite, Chemical composition

\section{Background}

The mudrocks constitute about $15.42 \%$ of the studied Paleozoic rock units. The study of their mineral composition and diagenesis as well as the abundance and distribution of their major and trace chemical components aim to understand the long history of these units.

Early and late Paleozoic rock unites recorded at southwestern Sinai, to the east of Abu Zenima city, lies between latitudes $28^{\circ} 57^{\prime} 00^{\prime \prime}$ and $29^{\circ} 05^{\prime} 00^{\prime \prime}$ $\mathrm{N}$ and longitudes $33^{\circ} 20^{\prime} 00^{\prime \prime}$ and $33^{\circ} 25^{\prime} 00^{\prime \prime}$ E, approximately, were studied (Fig. 1).

Early and late Paleozoic in the studied area varies either in thickness or in facies and is subdivided according to Soliman and Abu El Fetouh (1969) into seven formations, where the lower series comprises Sarabit El Khadim, Abu Hamata, and Adediya formations; the middle carbonate comprises the Um Bogma

\footnotetext{
* Correspondence: Abayazeed_s@yahoo.com

${ }^{1}$ Geological Sciences Department, National Research Center, Giza, Egypt Full list of author information is available at the end of the article
}

formation; and the upper series comprises El Hashash, Magharet El Maiah, and Abu Zarab formations (Fig. 2). The mudrock samples are recorded in early Paleozoic, Cambro-Ordovician, (Abu Hamata and Adediya formations (fms.)) and late Paleozoic, early Carboniferous (El Hashash and Magharet El Maiah fms.).

\section{Materials and methods}

Eighteen samples which represented early (12 samples) and late (6 samples) Paleozoic mudrocks were collected from the studied area. X-ray diffraction analysis was carried out at the Egyptian Mineral Resource Authority (E.M.R.A) using the Philips X-ray diffractometer (Type PW/1050) with $\mathrm{Ni}$ filter, $\mathrm{Cu}$ radiation, $\lambda=1.5 \mathrm{AA} 18 \AA$ at $30 \mathrm{kv}, 10 \mathrm{~mA}$, and a normal scanning speed $2 \theta / \mathrm{min}$ was used for seven clay samples which were selected to represent early (3 samples) and late (4 samples) Paleozoic rock units.

Nighen selected samples were chemically analyzed using X-Ray flourocense analysis (N.R.C.E Labs.) to 




Fig. 1 Location map of the studied area

determine the major oxide $(\mathrm{Si}, \mathrm{A} 1, \mathrm{Fe}, \mathrm{Mg}, \mathrm{Ca}, \mathrm{Na}$, $\mathrm{K}, \mathrm{P}, \mathrm{S}$, and $\mathrm{Cl}$ ) and trace element $(\mathrm{Ti}, \mathrm{Cr}, \mathrm{Y}, \mathrm{Co}, \mathrm{Mn}$, $\mathrm{V}, \mathrm{Ni}, \mathrm{Cu}, \mathrm{Zn}, \mathrm{Pb}, \mathrm{Sr}, \mathrm{Ba}, \mathrm{Rb}, \mathrm{Zr}, \mathrm{Ce}, \mathrm{Th}$, and $\mathrm{Ga}$ ) chemical components.

\section{Results}

\section{Mineralogical composition}

The X-ray diffraction analyses data of the studied clay samples is shown in (Table 1 and Figs. 3, 4 and 5) favor the presence of kaolinite and illite clay minerals.

\section{Chemical composition \\ Abundance and distribution of major oxides and trace elements}

The mudrocks constitute about $15.42 \%$ relative to the total thickness of the studied Paleozoic rock units. Major ( $\mathrm{Si}, \mathrm{A} 1, \mathrm{Fe}, \mathrm{Mg}, \mathrm{Ca}, \mathrm{Na}, \mathrm{K}, \mathrm{P}, \mathrm{S}$, and $\mathrm{Cl}$ ) and trace $(\mathrm{Ti}, \mathrm{Cr}, \mathrm{Y}, \mathrm{Co}, \mathrm{Mn}, \mathrm{V}, \mathrm{Ni}, \mathrm{Cu}, \mathrm{Zn}, \mathrm{Pb}, \mathrm{Sr}, \mathrm{Ba}$,
$\mathrm{Rb}, \mathrm{Zr}, \mathrm{Ce}, \mathrm{Th}$, and $\mathrm{Ga}$ ) components were shown in (Tables 2, 3, 7, and 8).

\section{Discussion}

Mineralogical composition

The detection of kaolinite and illite clay minerals in early and late Paleozoic clays favor their formation under alkaline waters and alkaline digenesis where they show stability in agreement with (Millot, 1970).

The study of clay mineral associations reported in the Paleozoic clays reveals that the environment of formation was an alkaline environment and that the origin of the clay minerals present is chlorite more probably than illite origin where illite can be derived from weathering of chlorite (Droste et al., 1962).

\section{Digenesis}

Clay minerals are particularly sensitive to pressure and temperature variations and to the chemical environment. This sensitivity is expressed in terms of their 


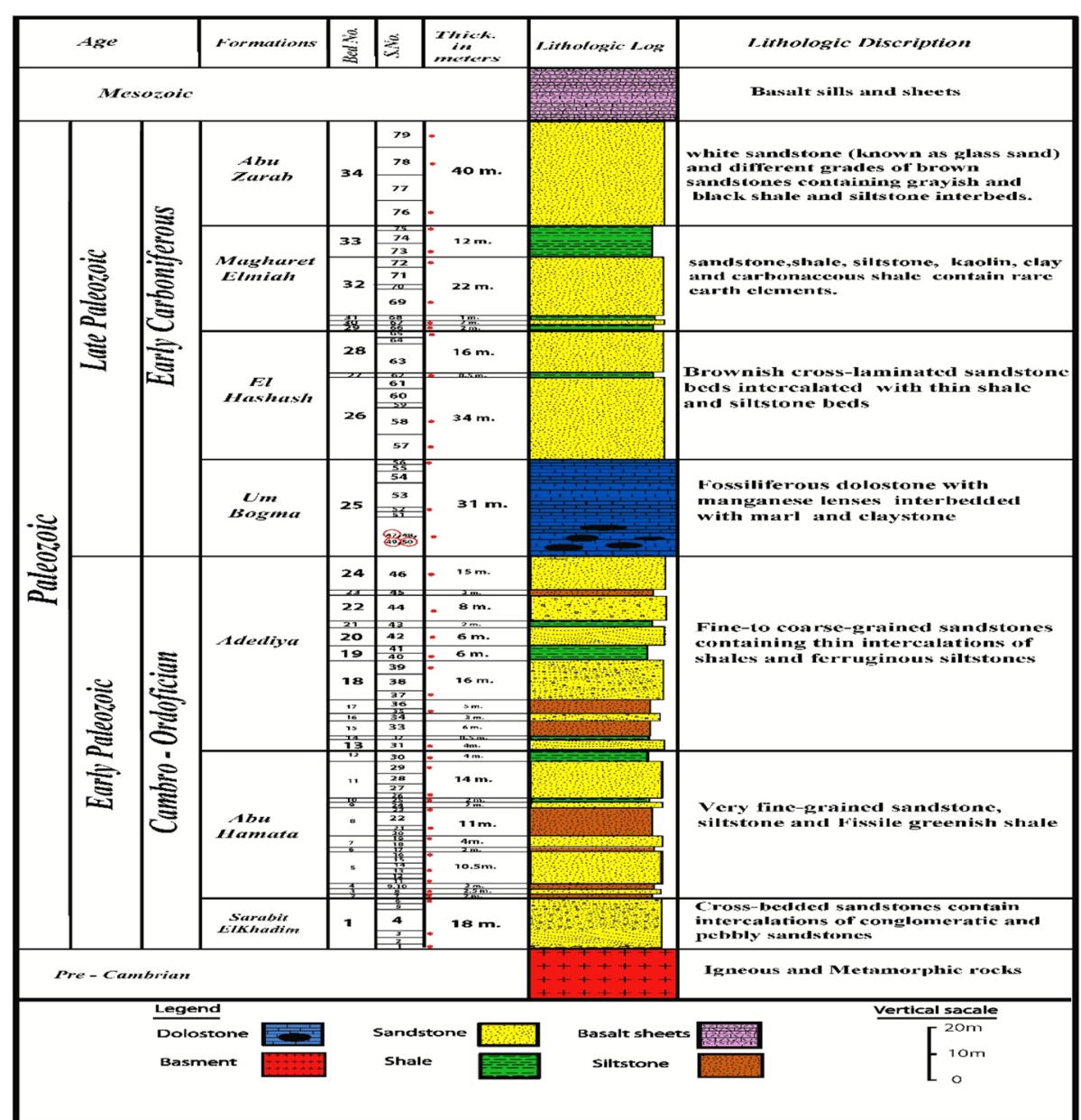

Fig. 2 Composite columnar lithologic section of Paleozoic sedimentary formations in southwestern Sinai

Table 1 X-ray diffraction data of different Paleozoic studied rock units

\begin{tabular}{|c|c|c|c|c|c|c|c|c|c|c|c|c|c|c|}
\hline \multirow[t]{2}{*}{ Age } & & & \multirow[t]{2}{*}{ Fms. } & \multirow{2}{*}{$\begin{array}{l}\text { S. } \\
\text { No. }\end{array}$} & \multirow{2}{*}{$\begin{array}{l}\text { Mineral } \\
\text { detected }\end{array}$} & \multicolumn{3}{|c|}{ Normal } & \multicolumn{3}{|c|}{ Glycolated } & \multicolumn{3}{|c|}{ Heated } \\
\hline & & & & & & $\overline{d A^{0}}$ & $1 / l_{0}$ & $2 \theta$ & $d A^{0}$ & $\mid / I_{0}$ & $2 \theta$ & $\overline{d A^{0}}$ & $1 / I_{0}$ & $2 \theta$ \\
\hline \multirow[t]{14}{*}{ Paleozoic } & \multirow[t]{8}{*}{ Late Paleozoic } & \multirow[t]{8}{*}{ Early Carboniferous } & \multirow[t]{6}{*}{ Magharet El Maiah } & \multirow[t]{2}{*}{75} & Kaolinite & 3.37 & 100 & 26.39 & 3.35 & 100 & 26.57 & - & - & - \\
\hline & & & & & Illite & 10.30 & 3.09 & 8.58 & 10.07 & 3.33 & 8.77 & 3.38 & 100 & 26.34 \\
\hline & & & & \multirow[t]{2}{*}{73} & Kaolinite & 3.36 & 100 & 26.45 & 26.53 & 100 & 3.35 & - & - & - \\
\hline & & & & & Illite & 10.24 & 3.94 & 8.63 & 10.22 & 3.94 & 8.65 & 3.37 & 100 & 26.44 \\
\hline & & & & \multirow[t]{2}{*}{66} & Kaolinite & 7.17 & 100 & 12.33 & 7.16 & 100 & 12.36 & - & - & - \\
\hline & & & & & Illite & 3.07 & 12.50 & 29.07 & 3.06 & 17.22 & 29.10 & 3.34 & 100 & 26.63 \\
\hline & & & \multirow[t]{2}{*}{ El Hashash } & \multirow[t]{2}{*}{62} & Kaolinite & 7.18 & 100 & 12.32 & 7.19 & 100 & 12.30 & - & - & - \\
\hline & & & & & Illite & 4.48 & 7.18 & 19.77 & 4.48 & 8.81 & 19.80 & 3.36 & 100 & 26.44 \\
\hline & \multirow[t]{6}{*}{ Early Paleozoic } & \multirow[t]{6}{*}{ Cambro-Ordovician } & \multirow[t]{2}{*}{ Adedia } & \multirow[t]{2}{*}{40} & Kaolinite & 7.21 & 100 & 12.26 & 7.22 & 100 & 12.24 & - & - & - \\
\hline & & & & & Illite & 10.16 & 73.63 & 8.69 & 10.18 & 59.77 & 8.68 & 3.37 & 100 & 26.40 \\
\hline & & & \multirow{4}{*}{$\begin{array}{l}\text { Abu } \\
\text { Hamata }\end{array}$} & \multirow[t]{2}{*}{30} & Kaolinite & 7.19 & 100 & 12.30 & 7.24 & 100 & 12.21 & - & - & - \\
\hline & & & & & Illite & 3.35 & 37.86 & 26.54 & 3.36 & 43.16 & 26.51 & 3.37 & 100 & 26.40 \\
\hline & & & & \multirow[t]{2}{*}{25} & Kaolinite & 7.18 & 100 & 12.32 & 7.23 & 100 & 12.23 & - & - & - \\
\hline & & & & & Illite & 10.08 & 13.30 & 8.76 & 10.25 & 15.14 & 8.62 & 10.07 & 100 & 8.77 \\
\hline
\end{tabular}


$\mathbf{A}$
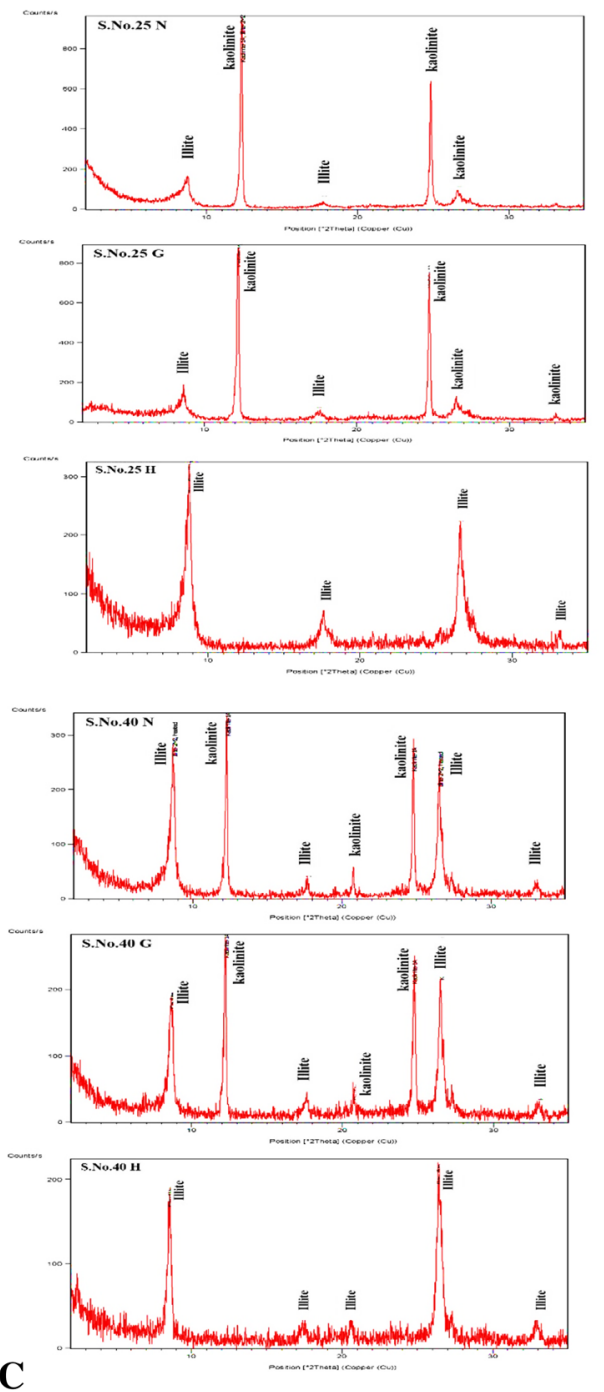

B


D

Fig. 3 X-ray diffraction pattern of oriented clay samples of Paleozoic mudrocks, a S. No. 25, b S. No. 30, c S. No. 40, and d S. No. 62

chemistry and mineralogy. According to Galan et al., (1985) Srodon, (1999) Carretero et al., (2002) Lopez Aguayo, (1990), and Merriman (2002), clay minerals mostly form from pre-existing minerals, primarily from rock-forming silicates by transformation and/or neo formation, where rocks are in contact with water, air, or steam.

\section{Weathering}

The weathering environment is usually sub-aerial. It involves physical disaggregation and chemical decomposition, leading to the transformation of original minerals into clay minerals. The factors controlling rock weathering include: rock type, climate (rainfall, chemical factor, and temperature), topography, and the presence of organisms and organic matter (Velde, 1992; Foley, 1999). The study area belongs to tropical zones and Mediterranean climates with seasonal contrast. Under these conditions, kaolinite is the main clay mineral components. Kaolinite together with some Illite can be neo-formed due to high rainfall and a temperate climate.

\section{Sedimentation}

A typical clay mineral distribution found from the coastline to the open sea is kaolinite-illite-smectite. In general, clay minerals of sedimentary sequences mainly reflect the climate, relief, and lithology of source areas. Kaolinite is a typical clay mineral formed by direct precipitation. 
A
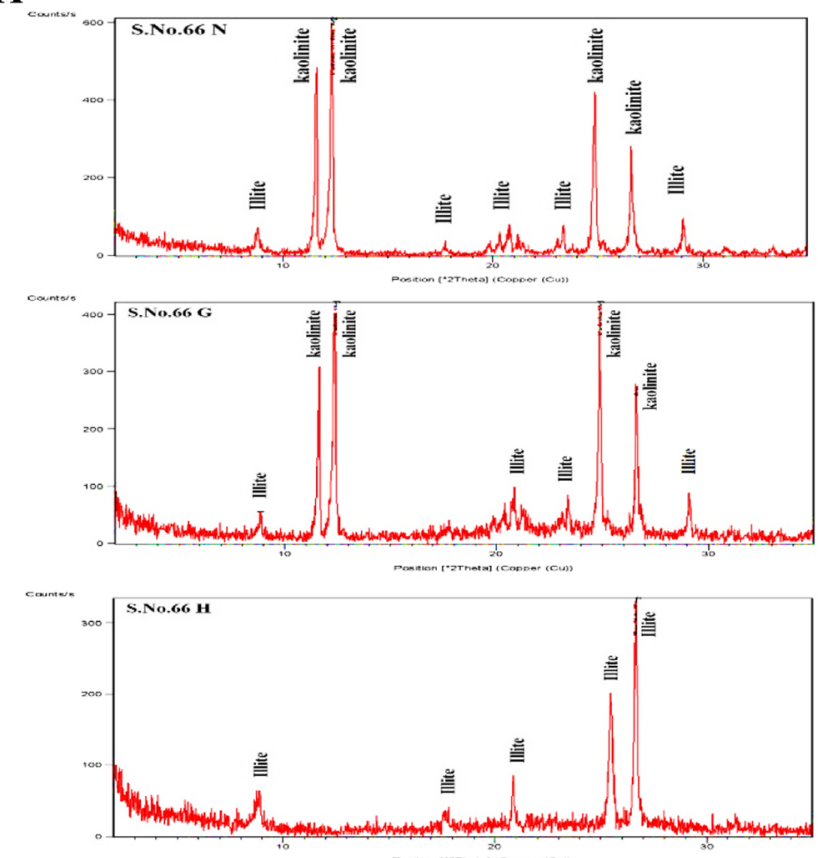

B

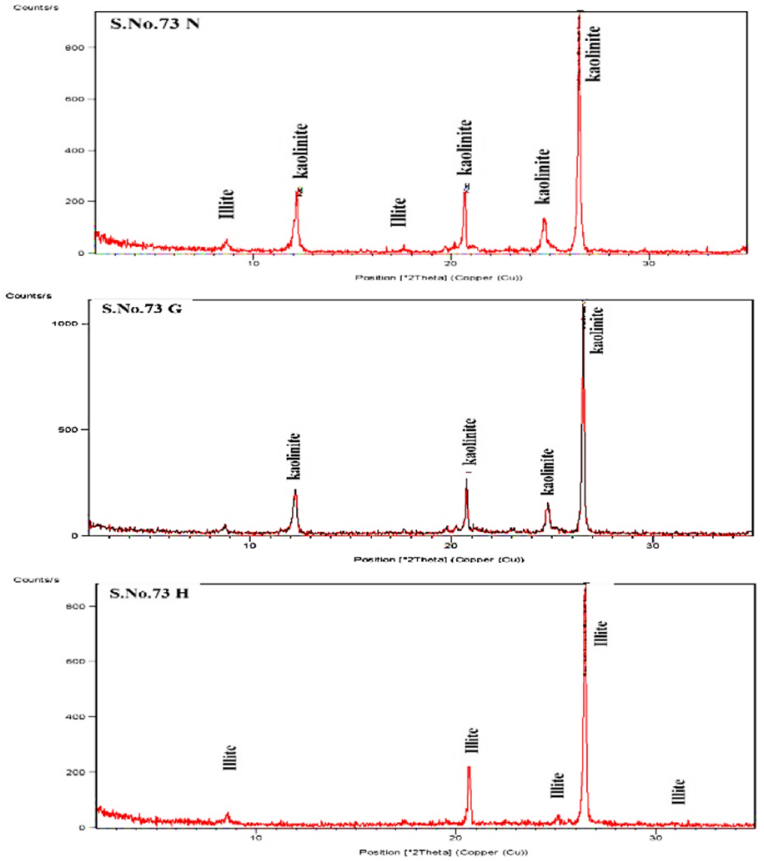

Fig. 4 X-ray diffraction pattern of oriented clay samples of Paleozoic mudrocks, a S. No. 66 and b S. No. 73

\section{Origin of kaolin's clay deposits}

Kaolinite can be formed by weathering (residual kaolin's) and hydrothermal activity (hydrothermal kaolin) or occur as an authigenic sedimentary mineral. Sedimentary kaolin's are composed of kaolinized material from a source area that was eroded, transported, and deposited in a continental or coastal environment.

The previous study about the mineralogy supports the assumption about the origin of kaolin clay deposits, whereas kaolinite can be neo-formed, transformed, as already mentioned, at high rainfall and a temperate climate which can transform muscovite and biotite into kaolinite together with some Illite.

\section{Chemical composition}

\section{Abundance and distribution of major oxides} Oxides forming silicates

The distribution of the average $\mathrm{SiO}_{2}$ content in early and late Paleozoic mudrocks is shown in (Tables 2 and 3) and Fig. 6. The distribution shows no particular trend for silica distribution with decrease in age from early towards late Paleozoic rock units.

Alumina is similar to silica in its occurrence, where silica and alumina tend to organize together into clay minerals, if they do not, alumina stays in situ with iron, whereas silica is removed with lime and magnesia (Millot, 1970).
According to Pettijohn et al. (1975) the silica/alumina ratio for Paleozoic mudrocks were computed (Table 4 and Fig. 7). It indicates that the grain size of the late Paleozoic mudrocks are coarser than that of early Paleozoic mudrocks; suggesting that; the late Paleozoic mudstone rock units are of the sandy type.

It seems that as Paleozoic mudrocks get younger they change from the clay to sandy through silty type and from immature to submature.

\section{Iron oxides}

The distribution of $\mathrm{Fe}_{2} \mathrm{O}_{3}$ within Paleozoic mudrocks shows no particular trend for distribution with decrease in age from early towards late Paleozoic rock units. This can be attributed to the fact that $\mathrm{Fe}_{2} \mathrm{O}_{3}$ can occur in a free state as pigment or in the silicate state.

\section{Calcium and magnesium oxides}

Calcium and magnesium are considered to be two ions with similar characteristics. The study shows that there is no particular trend for distribution of calcium and magnesium oxides with decrease in age from early towards late Paleozoic rock units. The relatively high values of $\mathrm{CaO}$ detected in Magharet El Maiah Formation can be attributed to the presence of calcareous material. 


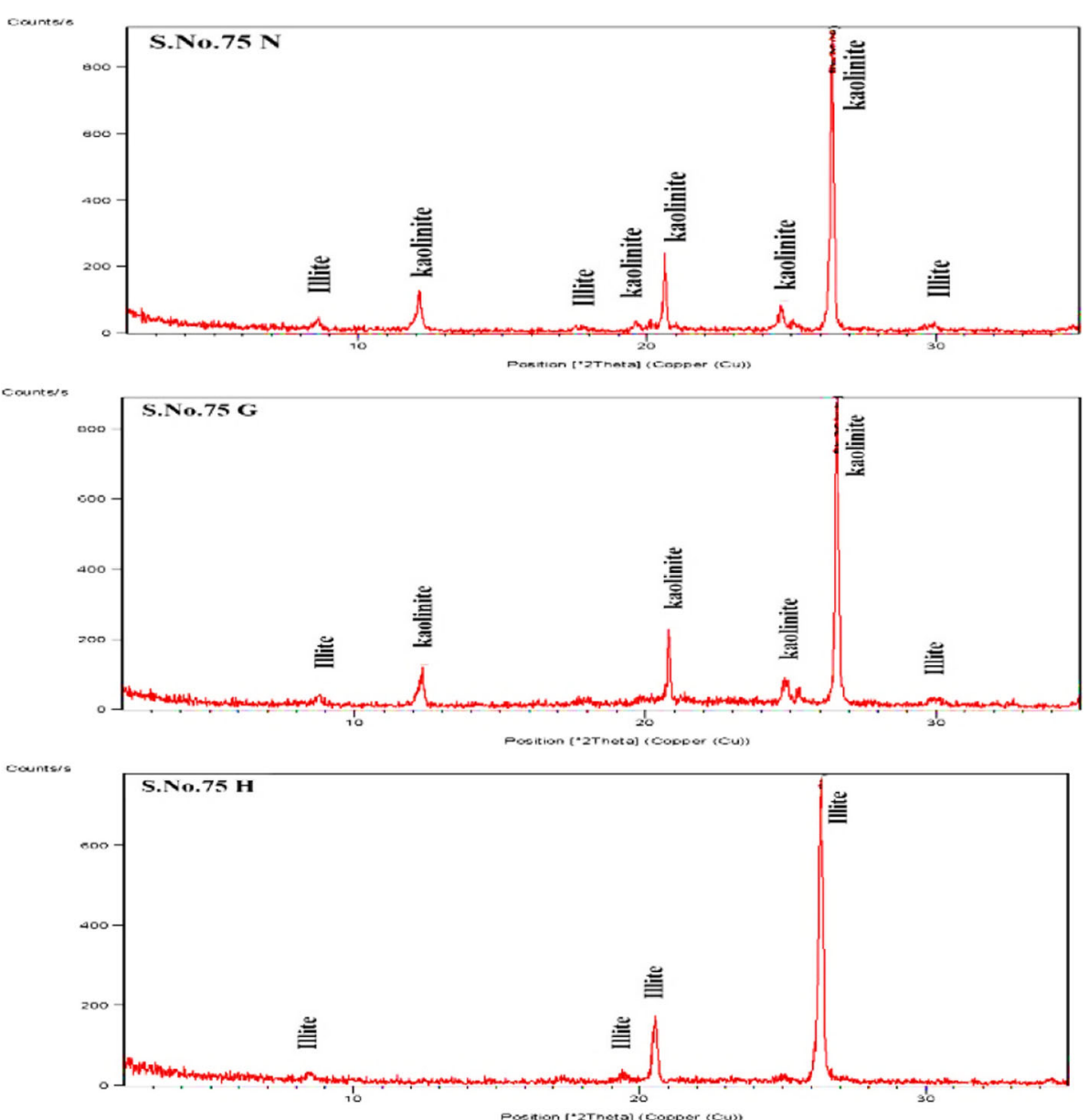

Fig. 5 X-ray diffraction pattern of oriented clay samples of Paleozoic mudrocks, S. No. 75

Vinogradov and Renov (1956) suggest that the surface of the crystalline basement available for weathering has decreased through time. The computed $\mathrm{Ca} / \mathrm{Mg}$ ratio for early and late Paleozoic studied mudrocks (Table 5 and Fig. 8) show values contradict with Vinogradov and Renov (1956), and this may be attributed to the topography of the studied rock units.

\section{Sodium and potassium oxides}

The distribution of both potassium and sodium oxide through early and late Paleozoic mudrocks shows a consistency. Whereas both show inconsistency with the distribution of aluminum oxide, this can be attributed to their presence as chlorides rather than in the silicate form.

Table 2 Chemical composition (major components in Wt.\%) of Paleozoic mudrocks

\begin{tabular}{|c|c|c|c|c|c|c|c|c|c|c|c|c|c|c|c|}
\hline \multicolumn{3}{|l|}{ Age } & \multirow{3}{*}{$\begin{array}{l}\text { Fms. } \\
\text { Magharet } \\
\text { El Maiah }\end{array}$} & \multirow{2}{*}{$\frac{\text { S. No. }}{75}$} & \multirow{2}{*}{$\frac{\mathrm{SiO}_{2}}{63.38}$} & \multirow{2}{*}{$\frac{\mathrm{Al}_{2} \mathrm{O}_{3}}{17.13}$} & \multirow{2}{*}{$\frac{\mathrm{Fe}_{2} \mathrm{O}_{3}}{0.63}$} & \multirow{2}{*}{$\frac{\mathrm{MgO}}{0.31}$} & \multirow{2}{*}{$\frac{\mathrm{CaO}}{0.34}$} & \multirow{2}{*}{$\frac{\mathrm{Na}_{2} \mathrm{O}}{0.65}$} & \multirow{2}{*}{$\frac{\mathrm{K}_{2} \mathrm{O}}{1.12}$} & \multirow{2}{*}{$\frac{\mathrm{P}_{2} \mathrm{O}_{5}}{0.07}$} & \multirow{2}{*}{$\frac{\mathrm{SO}_{3}{ }^{-2}}{4.38}$} & \multirow{2}{*}{$\frac{\mathrm{Cl}^{-}}{0.07}$} & \multirow{2}{*}{$\frac{\text { L.O.I }}{10.08}$} \\
\hline Paleozoic & Late Paleozoic & Early Carboniferous & & & & & & & & & & & & & \\
\hline & & & & 73 & 67.40 & 17.08 & 0.70 & 0.24 & 1.42 & 0.08 & 0.84 & 0.18 & 2.8 & 0.02 & 8.08 \\
\hline & & & & 66 & 39.24 & 17.02 & 0.62 & 0.50 & 10.00 & 0.30 & 0.53 & 0.09 & 17.42 & 0.24 & 12.4 \\
\hline & & & El Hashash & 62 & 69.68 & 24.00 & 0.38 & 0.20 & 0.38 & 0.06 & 0.44 & 0.09 & 0.06 & 0.01 & 3.67 \\
\hline & Early Paleozoic & Cambro-Ordovician & Adedia & 40 & 51.86 & 18.26 & 7.61 & 2.08 & 0.49 & 2.37 & 4.49 & 0.23 & 0.21 & 3.17 & 7.93 \\
\hline & & & & 35 & 59.55 & 22.02 & 1.17 & 1.82 & 0.57 & 0.50 & 5.54 & 0.13 & 0.04 & 2.35 & 5.19 \\
\hline & & & & 30 & 56.78 & 20.55 & 5.29 & 1.54 & 1.48 & 0.13 & 5.33 & 0.60 & 1.50 & 0.05 & 4.03 \\
\hline & & & & 25 & 54.70 & 23.57 & 6.19 & 1.99 & 0.56 & 0.89 & 5.75 & 0.24 & 0.15 & 0.53 & 4.08 \\
\hline & & & & 23 & 48.69 & 17.82 & 7.34 & 2.53 & 0.59 & 3.81 & 5.31 & 0.29 & 0.06 & 4.29 & 7.92 \\
\hline
\end{tabular}


Table 3 Average chemical composition (major components in wt.\%) of Paleozoic mudrocks

\begin{tabular}{|c|c|c|c|c|c|c|c|c|c|c|c|c|c|c|c|}
\hline \multicolumn{3}{|l|}{ Age } & \multirow{3}{*}{$\begin{array}{l}\text { Fms. } \\
\text { Magharet El } \\
\text { Maiah }\end{array}$} & \multirow{2}{*}{$\begin{array}{l}\text { S. No. } \\
\text { Min. }\end{array}$} & \multirow{2}{*}{$\begin{array}{l}\mathrm{SiO}_{2} \\
39.24\end{array}$} & \multirow{2}{*}{$\frac{\mathrm{Al}_{2} \mathrm{O}_{3}}{17.02}$} & \multirow{2}{*}{$\begin{array}{l}\mathrm{Fe}_{2} \mathrm{O}_{3} \\
0.62\end{array}$} & \multirow{2}{*}{$\begin{array}{l}\mathrm{MgO} \\
0.31\end{array}$} & \multirow{2}{*}{$\frac{\mathrm{CaO}}{0.34}$} & \multirow{2}{*}{$\frac{\mathrm{Na}_{2} \mathrm{O}}{0.08}$} & \multirow{2}{*}{$\frac{\mathrm{K}_{2} \mathrm{O}}{0.53}$} & \multirow{2}{*}{$\frac{\mathrm{P}_{2} \mathrm{O}_{5}}{0.07}$} & \multirow{2}{*}{$\frac{\mathrm{SO}_{3}^{-2}}{2.8}$} & \multirow{2}{*}{$\frac{\mathrm{Cl}^{-}}{0.02}$} & \multirow{2}{*}{$\frac{\text { L.O.I }}{8.08}$} \\
\hline Paleozoic & Late & Early & & & & & & & & & & & & & \\
\hline & & & & Max. & 67.40 & 17.13 & 0.70 & 0.50 & 10.00 & 0.65 & 1.12 & 0.18 & 17.42 & 0.24 & 12.44 \\
\hline & & & & Average & 56.67 & 17.08 & 0.65 & 0.35 & 3.92 & 0.34 & 0.83 & 0.11 & 8.20 & 0.11 & 10.20 \\
\hline & & & El Hashash & Average & 69.68 & 24.00 & 0.38 & 0.20 & 0.38 & 0.06 & 0.44 & 0.09 & 0.06 & 0.01 & 3.67 \\
\hline & Early & Cambro- & Adedia & Min. & 51.86 & 18.26 & 1.17 & 1.82 & 0.49 & 0.50 & 4.49 & 0.13 & 0.04 & 2.35 & 5.19 \\
\hline & & & & Max. & 59.55 & 22.02 & 7.61 & 2.08 & 0.57 & 2.37 & 5.54 & 0.21 & 3.17 & 7.93 & 0.21 \\
\hline & & & & Average & 55.71 & 20.14 & 4.39 & 1.95 & 0.53 & 1.44 & 5.02 & 0.18 & 0.13 & 2.76 & 6.56 \\
\hline & & & & Min. & 48.69 & 17.82 & 5.29 & 1.54 & 0.56 & 0.13 & 5.31 & 0.24 & 0.06 & 0.05 & 4.03 \\
\hline & & & & Max. & 56.78 & 23.57 & 7.34 & 2.53 & 1.48 & 3.81 & 5.75 & 0.60 & 1.50 & 4.29 & 7.92 \\
\hline & & & & Average & 53.39 & 20.65 & 6.27 & 2.02 & 0.88 & 1.61 & 5.46 & 0.38 & 0.57 & 1.62 & 5.34 \\
\hline
\end{tabular}

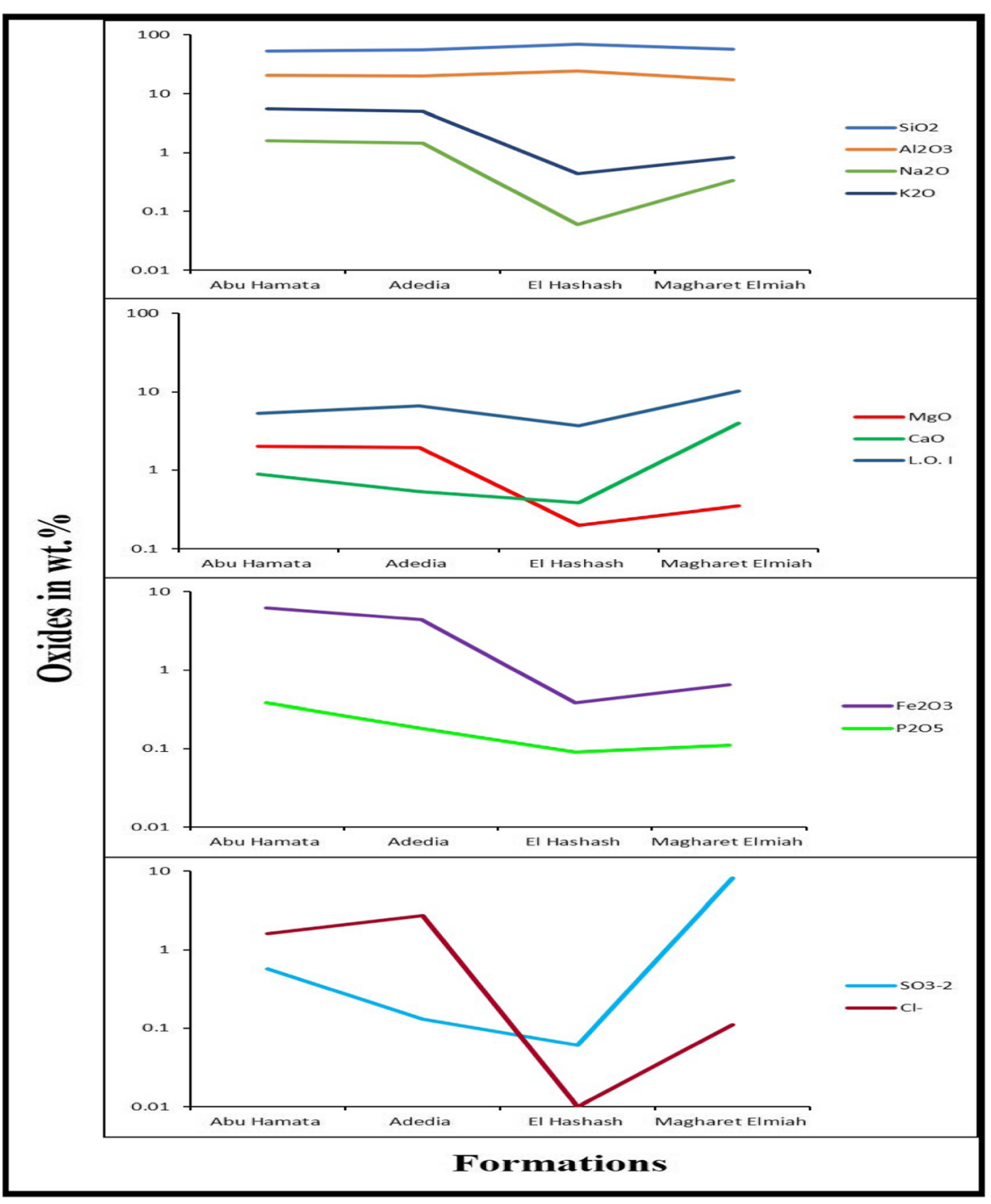

Fig. 6 Averages distribution curves of the studied mudrocks major chemical oxides 
Table $4 \mathrm{SiO}_{2} / \mathrm{Al}_{2} \mathrm{O}_{3}$ ratio of the studied Paleozoic mudrocks

\begin{tabular}{|c|c|c|c|c|}
\hline \multirow[t]{2}{*}{ Age } & \multicolumn{4}{|l|}{ Paleozoic } \\
\hline & \multicolumn{2}{|l|}{ Early Paleozoic } & \multicolumn{2}{|c|}{ Late Paleozoic } \\
\hline Formations & Abu Hamata & Adedia & El Hashash & Magharet El Maiah \\
\hline $\mathrm{SiO}_{2}$ & 53.39 & 55.71 & 69.68 & 56.67 \\
\hline $\mathrm{Al}_{2} \mathrm{O}_{3}$ & 20.65 & 20.14 & 24.00 & 17.08 \\
\hline Ratio & 2.58 & 2.77 & 2.90 & 3.32 \\
\hline
\end{tabular}

The computed K/Na ratio (Table 6 and Fig. 9) favors according to that crystalline igneous, metamorphic rocks contain as much potassium as sodium, and the $\mathrm{K} / \mathrm{Na}$ ratio equals 2.8 for clays.

$\mathrm{K} / \mathrm{Na}$ ratio are equally important whereas high ratios favor the formation of illite in agreement with Vinogradov and Ronov (1956). Also, the high values detected in the studied Paleozoic mudrocks can be attributed to formation in continental than marine environments in addition to the predominance of clays over silts (Garrels and Christ 1965, and Weaver, 1967).

\section{Phosphorous oxide}

According to Turekian and Wedepohl (1961), the average concentration of phosphorous oxide in shales is $0.07 \%$. The higher averages detected in Paleozoic mudrocks than that given by Turekian and Wedepohl (op. cit.) indicate that oxidizing conditions prevailed during the diagenesis of the deposited sediments causing fixation of the phosphate ions.

\section{Total sulphate}

Generally, the average content of the $\mathrm{SO} 3$ is higher than that given by Clarke (1924) $\left(\mathrm{SO}_{3}=0.64 \%\right)$. This
Table $5 \mathrm{Ca} / \mathrm{Mg}$ ratio of the studied Paleozoic mudrocks

\begin{tabular}{|c|c|c|c|c|}
\hline \multirow[t]{2}{*}{ Age } & \multicolumn{4}{|l|}{ Paleozoic } \\
\hline & \multicolumn{2}{|l|}{ Early Paleozoic } & \multicolumn{2}{|c|}{ Late Paleozoic } \\
\hline Formations & Abu Hamata & Adedia & El Hashash & Magharet El Maiah \\
\hline $\mathrm{Ca}$ & 0.63 & 0.38 & 0.27 & 2.80 \\
\hline $\mathrm{Mg}$ & 1.22 & 1.18 & 0.12 & 0.21 \\
\hline Ca/Mg Ratio & 0.52 & 0.32 & 2.25 & 13.33 \\
\hline
\end{tabular}

relatively high content indicates evaporation effect enhancing the formation of Paleozoic mudrocks in semirestricted environment.

\section{Soluble chlorides}

The soluble chloride content in Paleozoic mudrocks is relatively higher than that given by Clarke (1924, 180 $\mathrm{ppm}$ ) which indicates formation in semi-restricted environment with the prevalence of warm climate.

\section{Abundance and distribution of trace elements Titanium}

Titanium is the most abundant trace element recorded in Paleozoic mudrocks. The distribution of titanium content does not show any particular trend as the sediments get younger (Tables 7 and 8) and Fig. 10.

The higher titanium content of early Paleozoic Abu Hamata fm. and late Paleozoic Magharet El Maiah fm. mudrocks than those given by Turekian and Wedepohl (1961, $4600 \mathrm{ppm})$ can be attributed to the occurrence of titanium in probably authigenic anatase and rutile and is also structurally bound in iron minerals (Goldberg and Arrhenius, 1958). The lower titanium content of early Paleozoic; Adedia fm. and late Paleozoic; El Hashash fm.








mudrocks can be attributed to the occurrence authigenic anatase and rutile in relatively small amount.

Isayeva (1971) suggested that under reducing environments, titanium dissolved and can be adsorbed by clays. It seems that the prevailed conditions favor formation of titanium as hydrolysates at low alkaline $\mathrm{pH}$ values under reducing environment.

\section{Chromium}

The detected chromium in the studied mudrocks reveals no particular trend for distribution as the sediments get younger.

The higher chromium content detected in early and late Paleozoic mudrocks than those given by Turekian and Wedepohl (1961, $100 \mathrm{ppm}$ ) can be attributed to that the prevailed conditions favor formation of chromium as hydrolysates at low alkaline $\mathrm{pH}$ values under reducing environment. The lower $\mathrm{Cr}$ content than that given by Nicholis (1967) ( $\mathrm{Cr}>150 \mathrm{ppm})$ indicates that the environment of formation of early and late Paleozoic mudrocks was continental environment.

Table $6 \mathrm{~K} / \mathrm{Na}$ ratio of studied Paleozoic mudrocks

\begin{tabular}{|c|c|c|c|c|}
\hline \multirow[t]{2}{*}{$\overline{\text { Age }}$} & \multicolumn{4}{|l|}{ Paleozoic } \\
\hline & \multicolumn{2}{|l|}{ Early Paleozoic } & \multicolumn{2}{|c|}{ Late Paleozoic } \\
\hline Formations & Abu Hamata & Adedia & El Hashash & Magharet El Maiah \\
\hline K & 4.53 & 4.17 & 0.37 & 0.69 \\
\hline $\mathrm{Na}$ & 1.19 & 1.07 & 0.04 & 0.25 \\
\hline $\mathrm{K} / \mathrm{Na}$ & 3.81 & 3.90 & 9.25 & 2.76 \\
\hline
\end{tabular}

\section{Ytterbium}

The detected yttrium in the studied mudrocks reveals no particular trend for distribution as the sediments get younger. The detected average yttrium content in both early and late Paleozoic formation mudrocks show that the lower content relative to that given by Turekian and Wedepohl (1961, 90 ppm) can be attributed to the low alkaline $\mathrm{pH}$ values prevailed causing the depletion of $\mathrm{Y}$ element in the studied formations.

\section{Cobalt}

The detected cobalt in the studied mudrocks reveals no particular trend for distribution as the sediments get younger. The higher Co content detected in the studied early and late Paleozoic formation mudrocks than this given by Turekian and Wedepohl (1961, 74 ppm) can be attributed to the presence of magnesium although they have similarities in ionic radii and charge $\left(\mathrm{Co}^{2+}=0.83 \AA\right.$ and $\mathrm{Mg}^{2+} 0.080 \AA$ ) (Fig. 11). It is clear that the early and late Paleozoic formation mudrocks were formed under alkaline conditions causing enrichment by cobalt trace elements.

\section{Niobium}

Niobium can substitute for $\mathrm{Zr}$ in zircon, since this mineral is widely distributed in igneous rocks. According to Brookins (1988), niobium displays very low mobility under alkaline environment whereas, acidic environment increases the solubility of $\mathrm{Nb}$. The study reveals that the niobium content detected in the 


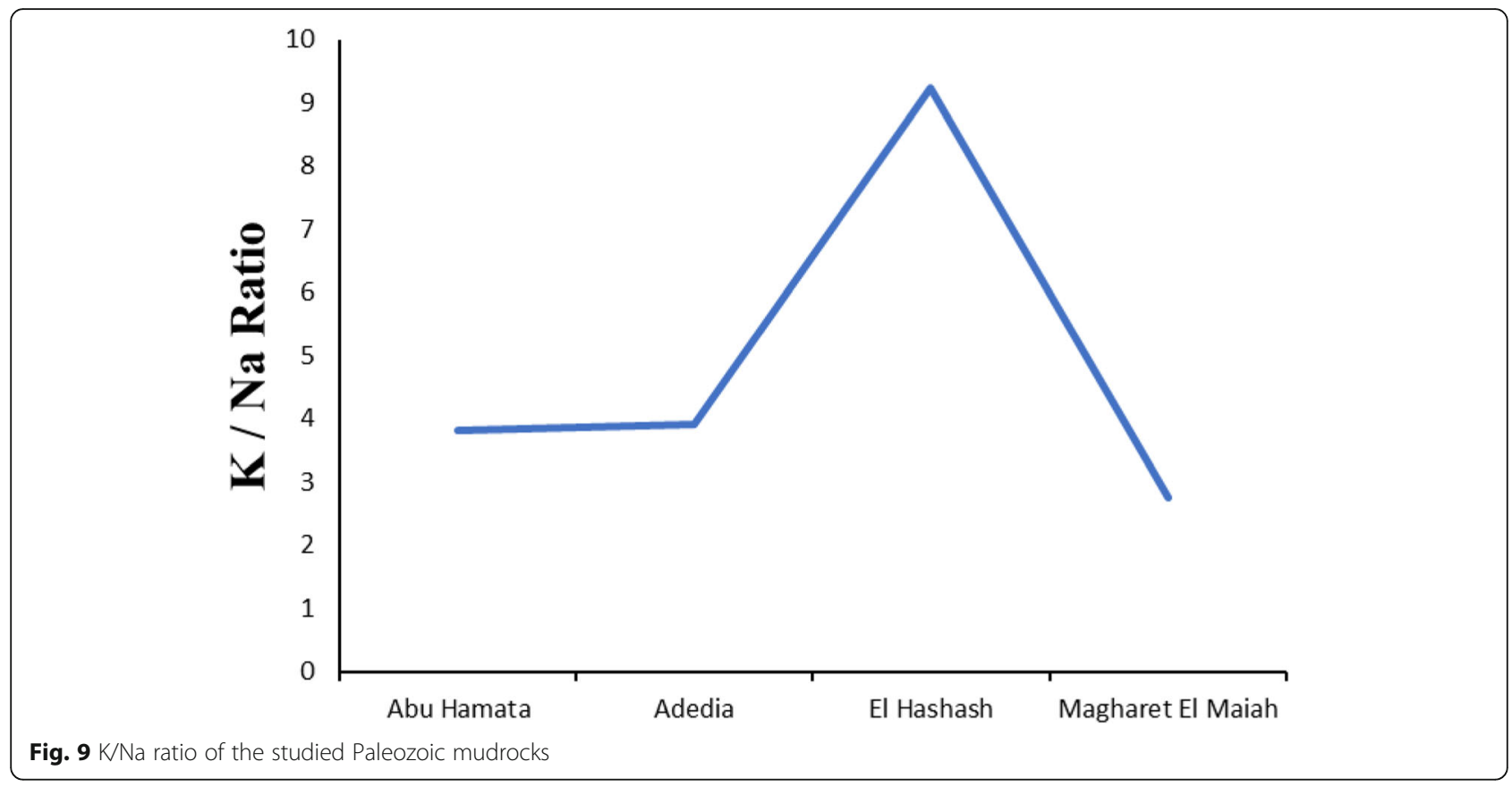

studied early and late Paleozoic formation mudrocks are higher than this given by Turekian and Wedepohl (1961, 14 ppm) and this can be attributed to not only the environment of formation but also the type of igneous rock detected.

\section{Manganese}

The manganese content which was lower than that given by Turekian and Wedepohl $(1961,850 \mathrm{ppm})$ can be attributed to that manganese is less mobile under oxidizing conditions and it will be mobilized in reducing environment (Manheim, 1961; Wedepohl, 1964 and Hartmann, 1964).

It seems that Paleozoic mudrocks were formed under reducing environments causing leaching of manganese and lowering its detected values.

\section{Vanadium}

The study of early and late Paleozoic formation mudrocks reveals higher average vanadium content relative to the average given by Turekian and Wedepohl (1961) $(V=120 \mathrm{ppm})$, supporting the idea that the prevailing environment was slightly reduced since vanadium's solution and migration take place only at relatively high redox potential.

\section{Nickel}

The Ni content which lower than the average given by Turekian and Wedepohl (1961, 80 ppm) can be attributed to formation under slightly reducing and alkaline environment.

\section{Copper}

The higher copper content than that given by Turekian and Wedepohl (1961, $50 \mathrm{ppm}$ ) can be attributed to the relatively higher amount of organic matter recorded in the studied mudrocks.

\section{Zinc}

The detected averages of zinc content show higher values than that given by Turekian and Wedepohl (1961, $90 \mathrm{ppm}$ ) in early Paleozoic and vice versa for late Paleozoic.

According to Krauskopf (1979), $\mathrm{Zn}^{2+}$ (ionic radii = $0.83 \AA$ ) follows $\mathrm{Mg}^{2+}$ (ionic radii $=0.80 \AA$ ) in its way of distribution. Figure 12 shows that zinc in the studied mudrocks follows that of magnesium which may indicate its adsorption on the clay minerals.

\section{Lead}

The detected lead average content shows higher values than that given by Turekian and Wedepohl (1961, 20 ppm), and this can be attributed to the environment of deposition which was alkaline, slightly reducing environment where the Eh was very low.

\section{Strontium}

The lower Sr content (early Paleozoic; Abu Hamata fm. and late Paleozoic; El Hashash fm.) and vice versa for (early Paleozoic; Adedia fm. and late Paleozoic; Magharet El Maiah fm.) than the average given by Turekian and Wedepohl (1961, 400 ppm) can be attributed to that $\mathrm{Sr}(1.21 \AA)$ can substitute both $\mathrm{Ca}^{2+}(1.08 \AA)$ and $\mathrm{K}^{+}(1.46 \AA)$ so its trend is a compromise between the 


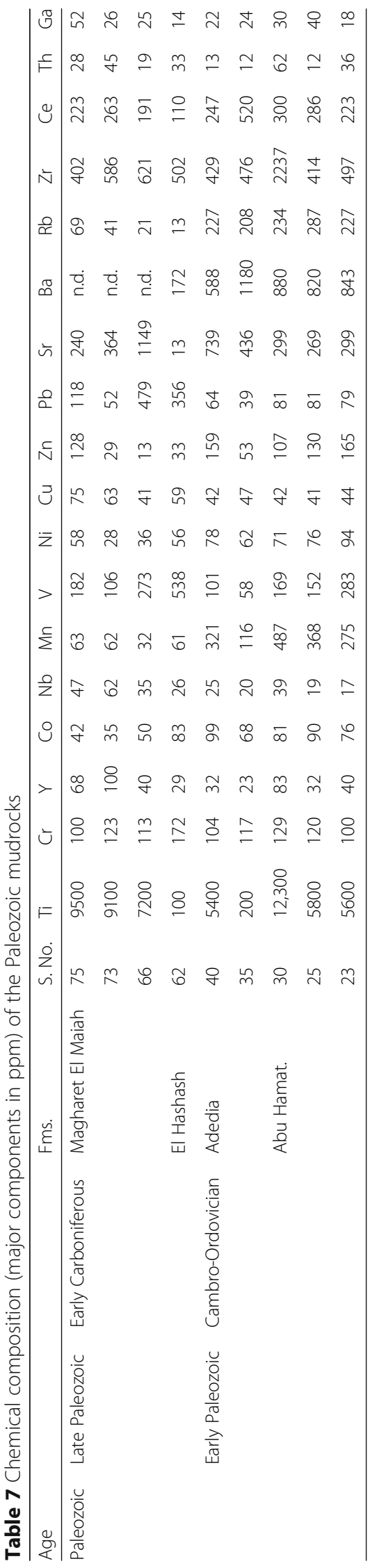











Fig. 10 Distribution curves of chemical components (trace elements ppm of Paleozoic mudrocks



Fig. 11 Correlation between cobalt and magnesium in the studied Paleozoic mudrocks 


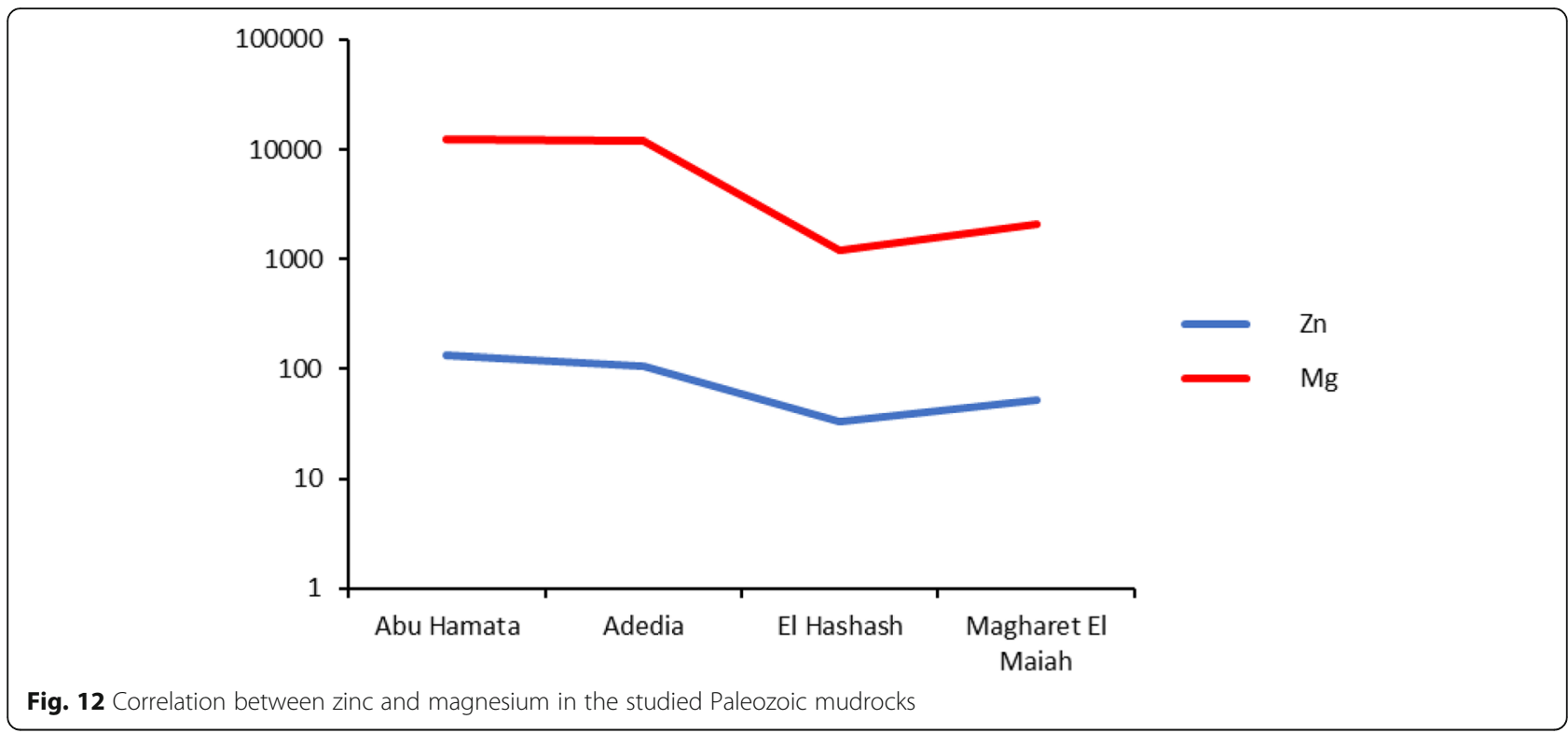

trends of the two major elements. Strontium appears to be a poor salinity indicator in mudrocks, is especially incorporated in the carbonate phase, and suffers all the diagenetic changes of the carbonate.

\section{Barium}

It is generally believed that the $\mathrm{Ba} / \mathrm{Sr}$ ratio (Table 9 and Fig. 13) increases with salinity. The higher barium average content detected for the Paleozoic mudrocks (except Late Paleozoic fms.) than that given by Turekian and Wedepohl (1961, 600;ppm) indicate formation under alkaline conditions causing leaching of barium from late Paleozoic formations and vice versa for early Paleozoic formations.

\section{Rubidium}

The higher rubidium average content detected for the Paleozoic mudrocks (except Late Paleozoic fms.) than that given by Turekian and Wedepohl (1961, 110 ppm) can be attributed to the relative concentration of both sodium and potassium oxides and to the type of clay mineral present, whereas rubidium follows both two major elements in their way of distribution.

Table $9 \mathrm{Br} / \mathrm{Sr}$ ratio of studied Paleozoic mudrocks

\begin{tabular}{|c|c|c|c|c|}
\hline \multirow[t]{2}{*}{ Age } & \multicolumn{4}{|l|}{ Paleozoic } \\
\hline & \multicolumn{2}{|l|}{ Early Paleozoic } & \multicolumn{2}{|c|}{ Late Paleozoic } \\
\hline Formations & Abu Hamata & Adedia & El Hashash & Magharet El Maiah \\
\hline $\mathrm{Ba}$ & 848 & 884 & 172 & 0 \\
\hline $\mathrm{Sr}$ & 289 & 588 & 13 & 584 \\
\hline $\mathrm{Ba} / \mathrm{Sr}$ ratio & 2.93 & 1.50 & 13.23 & 0 \\
\hline
\end{tabular}

\section{Zirconium}

According to Turekian and Wedepohl (1961), the average concentration of $\mathrm{Zr}$ content in mudrocks is 150 ppm showing that both early and late studied sandstones are characterized by abnormal Zirconium content due to adsorption onto clays.

\section{Cerium}

The study of early and late Paleozoic formation mudrocks reveal lower average cerium content relative to the average given by Turekian and Wedepohl (1961, 345 ppm), supporting the idea that the prevailing environment was reducing since cerium's solution and migration take place only at relatively high redox potential.

\section{Thorium}

The study of early and late Paleozoic formation mudrocks reveal higher average thorium content relative to the average given by Turekian and Wedepohl (1961, 7 ppm), supporting the idea that the prevailing environment was reducing since thorium's solution and migration take place only at relatively high redox potential.

\section{Gallium}

The great similarity between $\mathrm{Ga}^{3+}(r=0.80 \AA)$ and $\mathrm{Al}^{3+}$ $(r=0.61 \AA)$ and the consequent extensive substitution of $\mathrm{Ga}^{3+}$ for $\mathrm{Al}^{3+}$ in aluminosilicate minerals reveals that gallium flow aluminum in its way of distribution. Accordingly, Paleozoic mudrocks seem to be formed under relatively warm and slightly alkaline conditions in agreement with Corbel (1959). 




\section{Conclusions}

Mineralogical study reveals the presence of Kaolinite and Illite clay minerals. The detection of kaolinite and illite clay minerals favor that the environment of formation was alkaline, and the origin of the clay minerals present is chlorite more probably than illite origin where illite can be derived from weathering of chlorite. Diagenetic study reveals that kaolinite can be neo-formed, transformed at high rainfall and a temperate climate which can transform muscovite and biotite into kaolinite together with some Illite. Chemical composition study, abundance, behavior, and distribution of major and trace components reveal that the studied mudrocks seem to be formed under reducing alkaline environment.

\section{Acknowledgements}

Many thanks to all the contributing authors from Geological Sciences Dept., National Research Centre, and contributors from Geology Dept., Al-Azhar Univ., and Nuclear Material Authority .

\section{Authors' contributions}

SA contributed in chemical analysis. Al, DS, and AE contributed in collecting samples from field and mineralogical analysis. All authors shared in preparing the research. All authors read and approved the final manuscript.

\section{Funding}

No funding.

\section{Availability of data and materials}

Authors declare that the work data and material are available.

\section{Ethics approval and consent to participate}

Authors declare that the work is ethically approved and consent to participate.

\section{Consent for publication}

Authors declare that the work is consented for publication.

\section{Competing interests}

The authors declare that they have no competing interests.

\section{Author details}

${ }^{1}$ Geological Sciences Department, National Research Center, Giza, Egypt. ${ }^{2}$ Geology Department, Faculty of Science, Al-Azhar University, Cairo, Egypt. ${ }^{3}$ Nuclear Material Authority, Cairo, Egypt.

Received: 6 November 2018 Accepted: 16 May 2019

Published online: 30 July 2019

\section{References}

Brookins DG (1988) Eh-pH diagrams for geochemistry. Springer, Berlin, p 176

Carretero MI, Ruiz F, Rodriguez Ramırez A, Ca ceres L, Rodriguez Vidal J, Gonzalez Regalado ML (2002) The use of clay minerals and microfossils in paleoenvironmental reconstructions: the Holocene littoral of las Nuevas (Donana National Park, SW Spain). Clay Miner 37:93-103

Clark, F. H., (1924): The data of geochemistery, 5th ed. U. S. Geol. Surv. Bull. 770, 841

Corbel J (1959) Erosion en terrain calcaire (vitesse d'érosion et morphologie). In Annales de geographie, Armand Colin 68. no.366, pp. 97-120.

Droste JBJ, Bhattacharya H, Sunderman JA (1962) Clay mineral alteration in some Indiana soils, clays and clay minerals (9th Nat. Conf. 1960), pp 329-343

Foley NK (1999) Environmental characteristics of clays and clay mineral deposits. USGS Information Handout 4

Galan E, Gonzalez Lopez M, Fernandez Nieto C, Gonzalez Diez I (1985) Clay minerals of Miocene- Pliocene materials at the Vera basin. Geological Interpretation Mineralogica et Petrographica Acta 29A:259-266

Garrels EM, Christ CL (1965) Solutions, minerals and equilibria. Harper and Raw, New York, p 450

Goldberg ED, Arrhenius GOS (1958) Chemistry of pacific pelagic sediments. Geochim et Cosmochim Acta 13(2-3):153-198

Hartmann M (1964) ZurGeochemie von Mangan und Eisen in der Ostsee. Meyniana 14:3-20 https://doi.org/10.2312/meyniana.1964.14.3

Isayeva BA (1971) Relation between titanium and iron in the sediments of the Indian Ocean. Gcokhimiya, no.3, pp 310-317

Krauskopf KB (1979) Introduction to geochemistry. Me-Graw-Hill, New York, p 617

Lopez Aguayo, F. (1990): Aplicacion de la mineralogia de arcillas al ana' lisis de cuencas. In: Galan, E., Ortega Huertas, M. (Eds.), IX y X ReunionesCientificas. Sociedad Espanola de. Arcillas. Universidad de Granada, Spain, 69-86

Manheim F (1961) A geochemical profile in the Baltic Sea. Geochim Cosmochim Acta 25:52

Merriman RJ (2002) Contrasting clay mineral assemblages in British Lower Paleozoic slate belts: the influence of geotectonic setting. Clay Miner 37:207219

Millot T.G. (1970): Geology of clays. Keathering, sedimentology geochemistry. C.R. Acad. Sci. Fr., Chapman Hall, 429

Nicholis CD (1967) Trace elements in sediments: an assessment of their possible utility as depth indicators. Marine Geology Amsterdam 5:539-555

Pettijohn FJ, Fetter PE, Siever R (1975) Sedimentary rocks. Harper \& row, New York, p 630 
Soliman MS, Abu El-Fetouh MA (1969) Petrology of carboniferous sandstone in west Central Sinai. J Geol UAR 13(2):49-152

Srodon J (1999) Use of clay minerals in reconstructing geological processes: recent advances and some perspectives. Clay Miner 34:27-37

Turekian KK, Wedepohl Kh (1961) Distribution of elements in Sama major units of earth's crust. Geol Soc Amer BullV 72:175-192

Velde, B. (1992): Introduction to clay minerals. Chemistry, origins, uses and environmental significance. IX+. 198. London, Glasgow, New York, Tokyo, Melbourne, Madras

Vinogradov AP, Renov AB (1956) Evolution of the chemical composition of clays of the Russian platform. Geochem. 2:123-138

Weaver CE (1967) Potassium, illite, and the Ocean. Geochim Cosmochim Acta 31: 281-296

Wedepohl KH (1964) Untersuchungen am kupferschiefer in Nordwestdevtschland; einBeitragzurDeutung der

Genesebitumioosersedimente. Geochim Cosmochim Acta 28:305

\section{Publisher's Note}

Springer Nature remains neutral with regard to jurisdictional claims in published maps and institutional affiliations.

\section{Submit your manuscript to a SpringerOpen ${ }^{\circ}$ journal and benefit from:}

- Convenient online submission

- Rigorous peer review

- Open access: articles freely available online

- High visibility within the field

- Retaining the copyright to your article

Submit your next manuscript at $\boldsymbol{\wedge}$ springeropen.com 